\title{
The Predictive Power of
}

\section{Financial Variables: New Evidence from Australia $^{1}$}

\author{
Piyadasa Edirisuriya ${ }^{2}$
}

\begin{abstract}
Many studies have attempted to examine the predictive power of financial variables for numerous countries, but rarely does such research focus on future economic activities with respect to Australia. Financial variables are used to predict future economic events primarily because these variables are the closest indicators of the expectations and activities of investors and other economic agents. The recent global financial crisis (GFC) stemming from the subprime crisis shows that financial markets significantly influence global macroeconomic activities. In this study, we use major financial variables, such as the 90-day Treasury bill rate, 10-year Treasury bond rate, interest rate spread, and Australian stock index data. Similar to the housing prices in some other countries, those in Australia play a key role in future economic activities. In addition to financial variables, housing stock data is incorporated into our model for more realistic results, which are obtained by probit maximum likelihood estimation. We also use a general model for forecasting Australia's GDP growth until the third quarter of 2012. The results support previous research findings, indicating that financial variables are a useful tool for forecasting future economic activities in Australia.
\end{abstract}

Keywords: Financial variables, Interest rates, Term structure, Maximum likelihood estimation, Recession

JEL Code: C53

\footnotetext{
${ }^{1}$ Acknowledgement: We are grateful for the helpful comments and support of colleagues from the Department of Accounting and Finance, Monash University. This paper also benefited from the comments at the Multinational Finance Society meeting held in Roma, Italy in 2011. We are responsible for any remaining errors.

${ }^{2}$ Monash University, Australia. piyadasa.edirisuriya@monash.edu
} 


\section{Introduction}

Considerable research has been devoted to the power of financial variables to predict real economic activity. Most studies focus on using financial variables to predict future macroeconomic conditions, such as the future inflation levels, economic growth, or economic recessions. Stock returns, interest rates, and term structures are the most commonly used financial variables. These studies provide inconclusive results because of the diverse model specifications and variations used for different samples (e.g., Espinoza et al. 2009). Financial variables are used to predict future economic events primarily because these variables are the closest indicators of the expectations and activities of investors and other economic agents. Macroeconomists argue that there exists a strong relationship between nominal interest rate spread and output level (For example, Begum 1998). From a monetary policy perspective, applying a structural interpretation of this type of correlation facilitates appropriate recommendations for policy responses to future economic activities. The recent subprime mortgage defaults resulted in large losses for financial institutions. These losses led to economic downturns in many countries, thereby causing the global financial crisis (GFC). The GFC and the subsequent global recession reflect a strong relationship between financial variables and real economic activity.

Watson (1991), Estrella \& Mishkin (1998), Bernard \& Gerlach (1996), Atta-Mensha \& Tkacz (1998), Stock \& Watson (2003), Forni et al. (2003), Chauvet \& Potter (2005), Giacomini \& Rossi (2006), and Espinoza et al. (2009) examine the power of financial variables in forecasting future economic activities. These authors confirm the usefulness of applying financial variables to the contexts of the US, Canada, and European countries. A significant issue regarding the prediction of the macroeconomic outcomes of a country is using economic variables rather than financial variables in predictions. This issue may be addressed from three viewpoints. First, given the phenomenon of the global village and rapid capital movement, financial markets or financial variables are crucial for determining the future economic growth of a country. The GFC is regarded as strong evidence of this point. Second, financial variables can complement macroeconomic forecast models. Third, macroeconomic and financial variables have a significant relationship. Researchers also indicate that interest differentials are unbiased as predictors of future inflation differentials, and that term structures can predict future inflation changes, confirming the usefulness of financial variables in forecasting future economic events (Caporale \& Pittis 1998). The objective of the current work, therefore, is to validate the predictive performance of important financial variables, primarily the term structure of interest rates and similar variables, in predicting Australian recessions. We assume a relationship between interest rates and economic growth for following reasons:

(i) Interest rates and monetary policy are related and can affect economic growth.

(ii) The behaviours of participants in financial markets vary according to their expectations on economic growth.

As there is a theoretical explanation linking inflation to interest rate and output, we assume these reasons are linked to short- and long-term interest rates, term structure and are strong determinants of future economic activities (for a survey of literature on this see, Wheelock and Wohar, 2009). Following Bernard \& Gerlach (1996) for Europe, Atta-Mensha 
\& Tkacz (1998) for Canada, and Estrella \& Mishkin (1998) for the US, we use a probit model to analyse Australia's financial system and economic conditions. These studies are used as bases given that the financial system and economic conditions of North American countries and Europe are comparable to those of Australia. Using equivalent methodologies can yield robust results.

The rest of the paper is organised as follows. Section 2 presents a review of literature and Section 3 discusses the model and data. In Section 4, we explain the empirical results and in Section 5, we outline the limitations of the study. Section 6 concludes.

\section{Literature Review}

The US National Bureau of Economic Research (NBER) pioneered the application of leading economic indicators in forecasting future economic events. The NBER began developing indicator series long before computers were employed for prediction (Mitchell \& Burn 1938). Interest rate, however, was not among the indicators developed by the NBER in the early stages primarily because of the lack of variations in interest rates in the 1930s and 1940s (Atta-Mensha \& Tkacz 1998). Among the most important are Moore (1961), Moore \& Shiskin (1966), and Beckett (1961). Stock \& Watson (1993), Watson (1991), Estrella \& Hardouvelis (1991) and Hu (1993) present evidence that financial variables, such as interest rates and spreads, are powerful predictors of future economic activities. Specifically, Stock \& Watson (1993) and Friedman \& Kuttner (1992) confirm that the spread between the interest rates on commercial paper and Treasury bills significantly explains real economic activity. In succeeding work, Bernanke (1990) and Stock \& Watson (1993) find that the predictive power of paper-bill spread and interest rate weakened during the second half of the 1980s and the early 1990s. Other notable studies in the 1980s that examine the predictability of future real economic activity using financial variables include Harvey $(1988)$, Laurent $(1988,1989)$, and Atta-Mensha \& Tkacz (1998). There were number of significant studies done on this subject in the 1990s. Among them, Bernenke (1990), Estrella \& Hardouvelis (1991), Stock \& Watson (1993), Estrella \& Mishkin (1998), Bernard \& Gerlach (1996), and Atta-Mensha \& Tkacz (1998). The most recent research includes Stock \& Watson (2003), Moneta (2005), Giacomini \& Rossi (2006), Panopoulou (2006), and Junttila (2007). Espinoza et al. (2009) use vector autoregressions that include the GDP variables of the US and the euro area, as well as growth in the rest of the world (an aggregation of seven small countries) and a combination of selected financial variables. The authors also use impulse response (insample) tests to show that shocks to financial variables influence real economic activity.

Most of the aforementioned studies demonstrate that financial variables, such as the term structure of interest rates, stock returns, bond yield or spread, and money supply or monetary aggregates, contain valuable information on the future trends of real economic activity. The early practice of using stock market data to predict future economic activities has changed as a result of researchers employing many other similar variables, such as bond market data. These scholars argue that bond market data is a more accurate predictor than commonly used stock returns. Over the years, researchers have chosen various models and approaches for predicting future economic activities. Many predict, rather than quantify, such activities or recessions, while others forecast future economic activities using out-of-sample performance in addition to in-sample estimates. An extensively used model is the probit model, but various parametric and non-parametric methods have also been adopted. Wheelock and Wohar (2009) have surveyed substantial amount of literature on this issue. They have found out that most studies have been using linear regression techniques to 
forecast changes in output. Many others have been using time-varying parameter models such as Markov-switching models and smooth transition models. Most studies find that the term spread predicts output growth and recessions up to one year in advance.

Despite the substantial efforts devoted to studying financial variables as predictors, the few that focus on Australia are characterised by the use of stock returns, as well as shortand long-term bond yields, as predictors of future activities (e.g., Lowe 1992; Mishkin \& Simon 1994; Alles 1995; Fisher \& Felmingham 1998; Karunaratne 2002; Valadkhani 2003; Edirisuriya, 2005). Lowe (1992) provides empirical evidence that the spread between 10-year Treasury bonds and 180-day bank bills predicts the rate of change exhibited by several measures of real economic activity, but that such a spread has little predictive power over short- and long-term horizons. Alles (1995) shows that term spread more accurately forecasts cumulative future growth than marginal future growth. The author also finds that explanatory power begins to decline beyond 2 to 3 years into the future, regardless of the combination of long- and short-term yields used to measure the spread. Using Fisher effects, Mishkin \& Simon (1994) reveal that short-term changes in the Australian interest rate reflect changes in monetary policy, whereas long-run levels indicate inflationary expectations. The authors conclude that long-term interest rates should not be used to characterise the direction of monetary policy in Australia. Fisher \& Felmingham (1998) use the Australian yield curve as a leading indicator in predicting consumption growth. In this study, quarterly data from 1983 $4^{\text {th }}$ quarter to $19954^{\text {th }}$ quarter are employed to determine whether all 'real' spreads from a quarter to 2 years are significant. Fisher \& Felmingham's (1998) model also provide accurate out-of-sample predictions. On the basis of quarterly time series data from 1980:1 to 2002:2, Valadkhani (2003) acquires results that are consistent with previous studies on France, Germany, the UK, and Australia. The author finds that a 10\% increase in the interest rate spread between 10-year Treasury bonds and 90-day bank bills results in an approximately $4 \%$ rise in GDP growth over succeeding 7 to 9 quarters. Among all the studies on Australia, only two (Karunaratne 2002; Edirisuriya 2005) have thus far attempted to use financial variables to predict recessions. No efforts have been directed towards using a specific model (probit) with time series data to examine the predictive performance of financial variables under recession/no-recession situations for the country. The current work intends to fill these gaps.

\section{Model and Data}

We use regression analysis, following Bernard \& Gerlach (1996), Estrella \& Mishkin (1998), and Atta-Mensha \& Tkacz (1998). Specifically, we employ a probit model (a logit model is also a suitable alternative) capable of predicting future recessions in Australia. The advantage of using a probit model is that it demonstrates a clear outcome: whether Australia is in a recession in a particular period. The model is preferred over a linear probability model because in the latter, deriving predicted values, such as 0 or 1 , or values beyond the interval 0 to 1 , is difficult (Ramanathan 1998). If recession periods are taken as quarterly periods, during which economic growth has a negative value, the dependent variable can then be defined as follows:

$\mathrm{Z}_{\mathrm{t}} \quad=1$ if the Australian economy is in a recession at time $\mathrm{t}$

$=0$ otherwise

With the definition above, therefore, a standard linear regression model should be expressed in the form: 


$$
\mathrm{Z}_{\mathrm{t}}=\alpha_{0}+\alpha_{1} \mathrm{X}_{\mathrm{t}-\mathrm{k}}+\varepsilon_{\mathrm{t}}
$$

where $\mathrm{X}_{\mathrm{t}-\mathrm{k}}$ is the typical explanatory variable at time $t-k$. When the dependent variable is defined as above $\left(Z_{t}=1 ; 0\right.$ otherwise), using such a linear regression model yields spurious results (Greene 1993; Estrella \& Mishkin 1995). Because the proposed probit model enables the acquisition of 0 and 1 as predicted values, it can be expressed as:

$$
P\left(Z_{t}=1\right)=F\left(\alpha_{0}+\alpha_{1} X_{t-k}\right)
$$

where $\mathrm{F}$ is the normal cumulative distribution which is given as

$$
F\left(\alpha_{0}+\alpha_{1} X_{t-k}\right)=\int_{-\infty}^{\left(\alpha_{0}+\alpha_{1} X_{t-k}\right)} \frac{1}{\sqrt{2 \pi}} e^{\frac{\left(-Z^{2}\right) / 2}{2} d Z}
$$

Coefficients $\alpha_{0}$ and $\alpha_{1}$ are estimated using the maximum likelihood function given as

$\log \left(L\left(Z, \alpha_{0}, \alpha_{1}\right)\right)=\sum_{t=1}^{N}\left(Z, \log \left(\left(F\left(\alpha_{0}+\alpha_{1} X_{t-k}\right)\right)+\left(1-Z_{t}\right) \log \left(1-F\left(\alpha_{0}+\right.\right.\right.\right.$ $\left.\left.\left.\left.\alpha_{1} X_{t-k}\right)\right)\right)\right)$

In the estimation, the $\mathrm{P}$ value can be taken as the probability of a recession occurring, depending on the obtained value of the independent variable. We use pseudo $\mathrm{R}^{2}$ as the goodness-of-fit measure for the probit model. Estrella (1995) defines pseudo $\mathrm{R}^{2}$ as:

$$
\text { Pseudo-R } \mathrm{R}^{2}=1-\left(\frac{\log L_{u}}{\log L_{C}}\right)^{\frac{2}{n} \log L_{C}}
$$

where $L_{u}$ is the value of the likelihood of the estimated model and $L_{c}$ denotes the value of a model that contains only a constant term. Pseudo $\mathrm{R}^{2}$ is chosen for this study because it intuitively corresponds to the commonly used linear $\mathrm{R}^{2}$ when its values are far from end points 0 and 1 (Estrella \& Mischkin 1998). This correspondence shows that a pseudo $\mathrm{R}^{2}$ value closer to 1 indicates stronger explanatory power.

We use major financial variables in the prediction. In our model, TN represents the Treasury note rate, TB is the Treasury bond rate, REIT denotes the Australian Real Estate Investment Trusts index data, SE is the Australian Stock Market index (All Ordinaries index) and M3 refers to broad money supply. Similar to Stock \& Watson (2001), we obtain quarterly data (from the first quarter of 1960 to the fourth quarter of 2009) on the GDP, M3, and All Ordinaries index. Data on REIT, Treasury bonds, and 90-day bank bills dates back to 1970 . TN represents short-term interest rates while TB is to represent medium to longer term rates. TN and TB are used basically to capture short to longer term growth impacts. REIT is important as Australia's economic growth has a significant influence due to increased or decreased housing market activities. Similarly, we use SE and M3 both have influence on economic activities, to prediction purposes. All the data come from the ABS Time Series and the Reserve Bank of Australia Bulletins.

In addition to probit model estimations, a general model is also used to forecast Australia's future GDP growth a few quarters ahead (Stock \& Watson, 2001). A GDP forecast reveals whether Australia will experience a recession in the future. 


\section{Empirical Results}

The results are based on equations estimated over the entire sample period (Table 1); these findings are obtained using probit maximum likelihood estimations. Table 2 shows the results for individual variable estimations. As previously stated, the financial variables used are 90day bank bill rates (90BBL), 10-year Treasury bond rates (10YTB), real estate investment trust index values (REIT), money supply values (M3), and the Australian Stock Exchange index data (ALLORD). All the data are the change values from the previous quarter. We believe using change values captures short- and long-term effects. As indicated by many previous studies, financial variables are highly useful in predicting future economic activities. The overall sample results in the current work indicate that some variables effectively predict long-term effects (90BBL), whereas a few variables effectively predict short-term prospects (M3 and ALLORD). Changing the forecast horizon (quarterly periods) from k-0 to k-6 generates the estimates used to examine the capability of different financial variables to predict recessions a number of periods ahead. Testing for up to eight quarterly periods is conducted, but we do not discuss these here because results begin to change to a negligible level after the sixth quarter. Although the results vary, the predictive power of almost all the variables is significant when estimation is performed individually. When the full sample is considered, however, a few variables become nonsignificant, a result that may be attributed to the effect of other variables; financial markets are not influenced by a single particular variable. M3 and ALLORD begin to lose predictive power after 2 quarters, whereas 90BBL and 10YTB strengthen after the second and third quarters, relative to the results of previous studies. In the full sample estimation, REIT does not show any significance, an unexpected result given that real estate investments significantly affect Australian economic growth. In individual estimations, however, REIT shows remarkable significance (Table 2). Tables 1 and 2 show the coefficient values, slandered error, $\mathrm{T}$ ratio, and pseudo $\mathrm{R}^{2}$ values. When the variables are individually estimated, all the variables are significant at the $5 \%$ level after the second quarter, except 90BBL.

Figure 1 depicts the changes in each variable during the sample period, and Figures 2 and 3 show the GDP forecast for Australia up to 2012. The idea of incorporating the GDP forecast is to verify the relationship between the forecast GDP and the other variables, namely, 10YTB, REIT, 90BBL, and ALLORD. If predicted values are considerably different from actual values, it may imply a weak relationship. Figure 2 is showing the GDP forecast and a 95\% confidence interval. In our analysis the behaviour of most of the variables is similar to that of the forecast GDP, confirming the usefulness of financial variables in predicting future economic activities. Figure 3 confirms that actual GDP trend and the forecast GDP trend are very much similar indicating that predictive abilities of selected variables are robust. 
Table 1

Maximum Likelihood Estimations for the Full Sample Period ( $k=$ forecast horizon)

\begin{tabular}{|c|c|c|c|c|c|c|c|}
\hline & Statistics & M3 & REIT & 10YTB & 90BBL & ALLORD & \\
\hline \multirow[t]{4}{*}{$k=0$} & Coefficient & 0.0065 & 0.0018 & 0.0721 & 0.0229 & -0.0021 & \\
\hline & St. error & 0.0024 & 0.0014 & 0.0817 & 0.0629 & 0.0008 & \\
\hline & t- ratio & 2.6882* & 1.3045 & 0.8822 & 0.3641 & $2.4662 *$ & \\
\hline & Pseudo R2 & & & & & & 0.1723 \\
\hline \multirow[t]{4}{*}{$k-1$} & Coefficient & 0.0051 & 0.0011 & 0.0694 & 0.0176 & -0.0016 & \\
\hline & St. error & 0.0022 & 0.0014 & 0.0806 & 0.0618 & 0.0008 & \\
\hline & t- ratio & $2.2621 *$ & 0.804 & 0.8615 & 0.2851 & $2.0148 *$ & \\
\hline & Pseudo R2 & & & & & & 0.1557 \\
\hline \multirow[t]{4}{*}{$k-2$} & Coefficient & 0.0017 & -0.0008 & 0.2076 & -0.0995 & -0.0003 & \\
\hline & St. error & 0.0021 & 0.0013 & 0.0848 & 0.066 & 0.0007 & \\
\hline & t- ratio & 0.7891 & -0.5842 & $2.4479 *$ & -1.5071 & -0.4939 & \\
\hline & Pseudo R2 & & & & & & 0.1417 \\
\hline \multirow[t]{4}{*}{$k-3$} & Coefficient & 0.0006 & -11 & 0.3192 & -1937 & -1.67 & \\
\hline & St. error & 0.0021 & 0.0013 & 0.0898 & 0.0706 & 0.0007 & \\
\hline & t- ratio & 0.2783 & -0.853 & $3.5537^{*}$ & -2.743 & -0.0225 & \\
\hline & Pseudo R2 & & & & & & 0.1621 \\
\hline \multirow[t]{4}{*}{$k-4$} & Coefficient & -0.0016 & -4.06 & 0.2675 & -0.1591 & -0.0001 & \\
\hline & St. error & 0.0039 & 0.0016 & 0.0815 & 0.0629 & 0.0008 & \\
\hline & t- ratio & -0.4087 & -0.0243 & $3.2810 *$ & $2.5280^{*}$ & -0.1452 & \\
\hline & Pseudo R2 & & & & & & 0.1643 \\
\hline \multirow[t]{4}{*}{$k-5$} & Coefficient & -0.0025 & 0.0008 & 0.3373 & -0.2292 & -0.0002 & \\
\hline & St. error & 0.0041 & 0.0016 & 0.0899 & 0.072 & 0.0008 & \\
\hline & t- ratio & -0.6157 & 0.4979 & 3.7501* & $3.1831^{*}$ & -0.3341 & \\
\hline & Pseudo R2 & & & & & & 0.1895 \\
\hline \multirow[t]{5}{*}{$k-6$} & Coefficient & 0.0015 & 0.0039 & 0.4092 & -0.3141 & -0.0019 & \\
\hline & St. error & 0.0044 & 0.0021 & 0.09862 & 0.0837 & 0.0009 & \\
\hline & & & & & - & - & \\
\hline & t- ratio & 0.3414 & 1.806 & 4.1498* & 3.7189* & $2.0655^{*}$ & \\
\hline & Pseudo R2 & & & & & & 0.2629 \\
\hline
\end{tabular}

* Significant at the 5\% level 
Table 2

Maximum Likelihood Estimation Using One Variable at a Time ( $k=$ forecast horizon)

\begin{tabular}{|c|c|c|c|c|c|c|c|}
\hline & $k=0$ & $\mathrm{k}-1$ & $\mathrm{k}-2$ & $k-3$ & $k-4$ & $k-5$ & $k-6$ \\
\hline \multicolumn{8}{|l|}{ M3 } \\
\hline Coefficient & -0.1943 & -0.1898 & -0.1873 & -0.184 & -0.2165 & -0.2099 & -0.2064 \\
\hline \multirow[t]{2}{*}{ St. error } & 0.0794 & 0.0794 & 0.0794 & 0.0795 & 0.0827 & 0.0827 & 0.0827 \\
\hline & - & - & - & - & - & - & - \\
\hline t- ratio & $2.4468^{*}$ & $2.3903^{*}$ & $2.3575^{*}$ & $2.3144^{*}$ & $2.6163^{*}$ & $2.5381^{*}$ & $2.4954^{*}$ \\
\hline Pseudo R2 & 0.0354 & 0.0338 & 0.0329 & 0.0317 & 0.0421 & 0.0395 & 0.0382 \\
\hline \multicolumn{8}{|l|}{ REIT } \\
\hline Coefficient & -0.9486 & -0.9847 & -0.9636 & -0.8574 & -0.8897 & -0.8374 & -0.796 \\
\hline \multirow[t]{2}{*}{ St. error } & 0.2857 & 0.2884 & 0.2853 & 0.2753 & 0.2812 & 0.2762 & 0.272 \\
\hline & - & - & - & - & - & - & - \\
\hline t- ratio & 3.3193* & $3.4141^{*}$ & 3.3769* & $3.1136^{*}$ & $3.1636^{*}$ & $3.0316^{*}$ & $2.9257^{*}$ \\
\hline Pseudo R2 & 0.0743 & 0.0794 & 0.0771 & 0.0636 & 0.0678 & 0.0614 & 0.0565 \\
\hline \multicolumn{8}{|l|}{ 10YTB } \\
\hline Coefficient & 0.9966 & 0.9644 & 1.0166 & 1.0482 & 1.1538 & 1.1434 & 1.1459 \\
\hline St. error & 0.3115 & 0.3127 & 0.3179 & 0.3193 & 0.33 & 0.3304 & 0.331 \\
\hline t- ratio & 3.1989* & $3.0837^{*}$ & $3.1977 *$ & $3.2820 *$ & $3.4964 *$ & $3.4600^{*}$ & $3.4619^{*}$ \\
\hline Pseudo R2 & 0.0603 & 0.0562 & 0.061 & 0.0646 & 0.076 & 0.0745 & 0.0747 \\
\hline \multicolumn{8}{|l|}{$90 \mathrm{BBL}$} \\
\hline Coefficient & 0.6627 & 0.5944 & 0.4902 & 0.4103 & 0.5167 & 0.4803 & 0.4509 \\
\hline St. error & 0.245 & 0.2421 & 0.2437 & 0.2459 & 0.2525 & 0.2546 & 0.2575 \\
\hline t- ratio & 2.7038* & $2.4545^{*}$ & 2.0118 & 1.6683 & 2.0465 & 1.8865 & 1.7508 \\
\hline Pseudo R2 & 0.042 & 0.0345 & 0.023 & 0.0158 & 0.0245 & 0.0208 & 0.0179 \\
\hline \multicolumn{8}{|l|}{ ALLORD } \\
\hline Coefficient & -0.357 & -0.3555 & -0.3359 & -0.3109 & -0.3549 & -0.3604 & -0.3719 \\
\hline \multirow[t]{2}{*}{ St. error } & 0.1112 & 0.1111 & 0.1096 & 0.1085 & 0.1132 & 0.1135 & 0.115 \\
\hline & - & - & - & - & - & - & - \\
\hline t- Ratio & $3.2105^{*}$ & 3.1989* & $3.0627^{*}$ & $2.8651^{*}$ & $3.1325^{*}$ & $3.1747^{*}$ & $3.2335^{*}$ \\
\hline Pseudo R2 & 0.0641 & 0.0636 & 0.0577 & 0.05 & 0.0625 & 0.0644 & 0.0673 \\
\hline
\end{tabular}

* Significant at the 5\% level 
Figure 1

\section{Changes in each variable during the period of estimation}

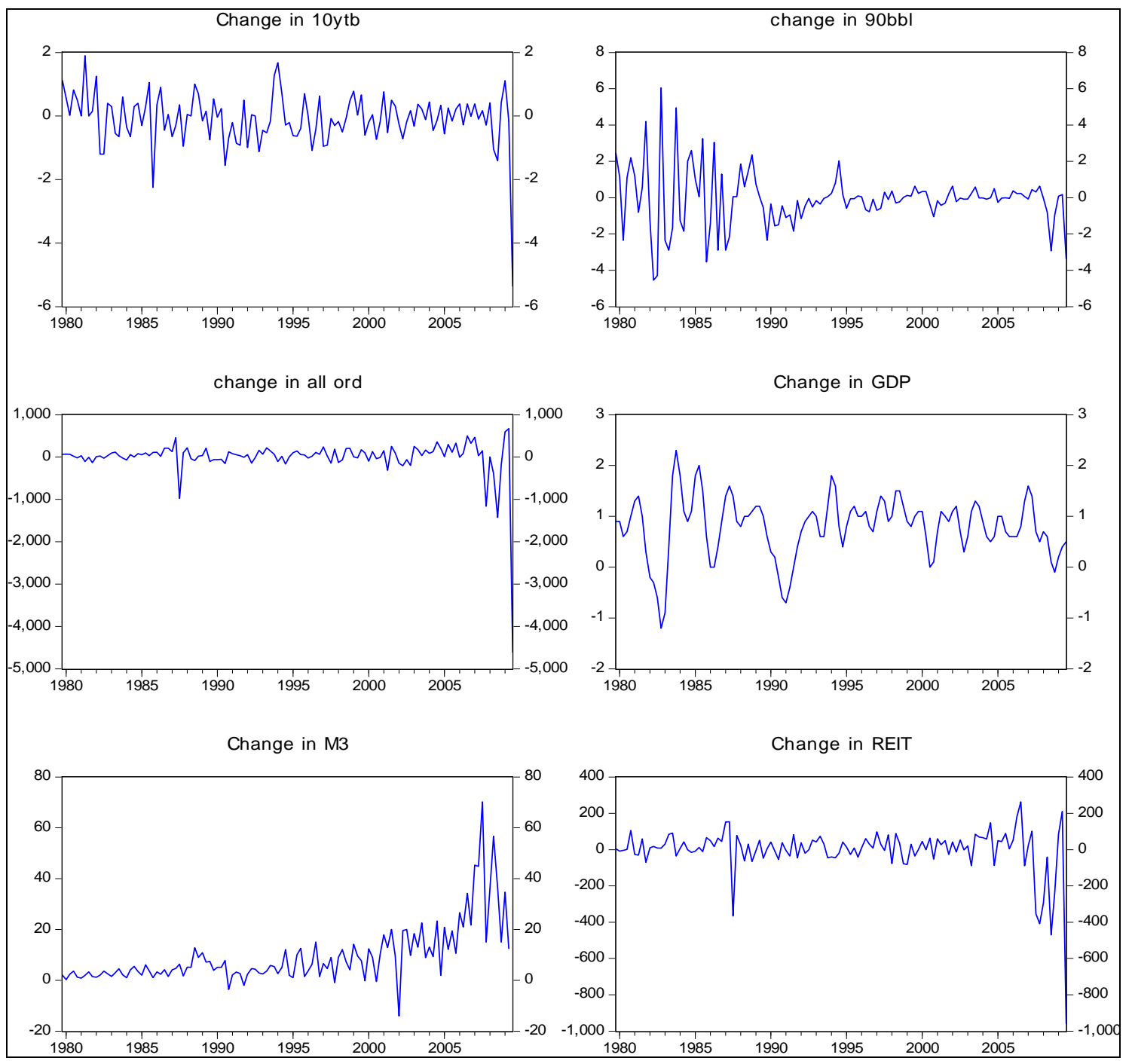

Figure 2

Evaluation results for GDP forecast

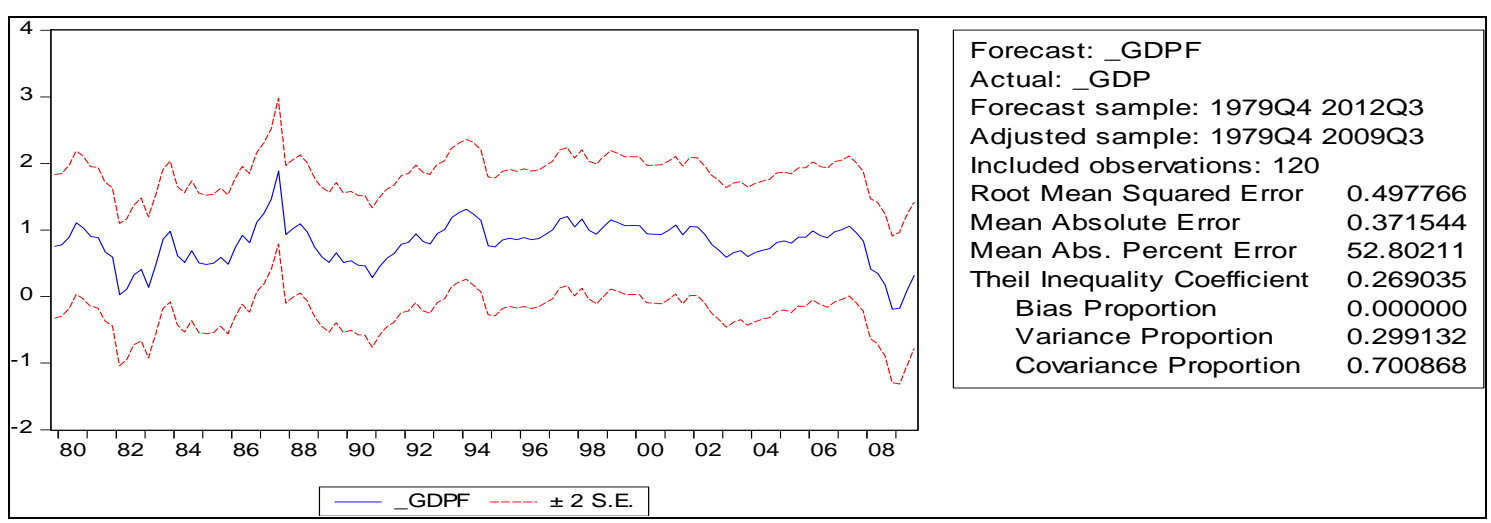


Figure 3

Actual and forecast GDP

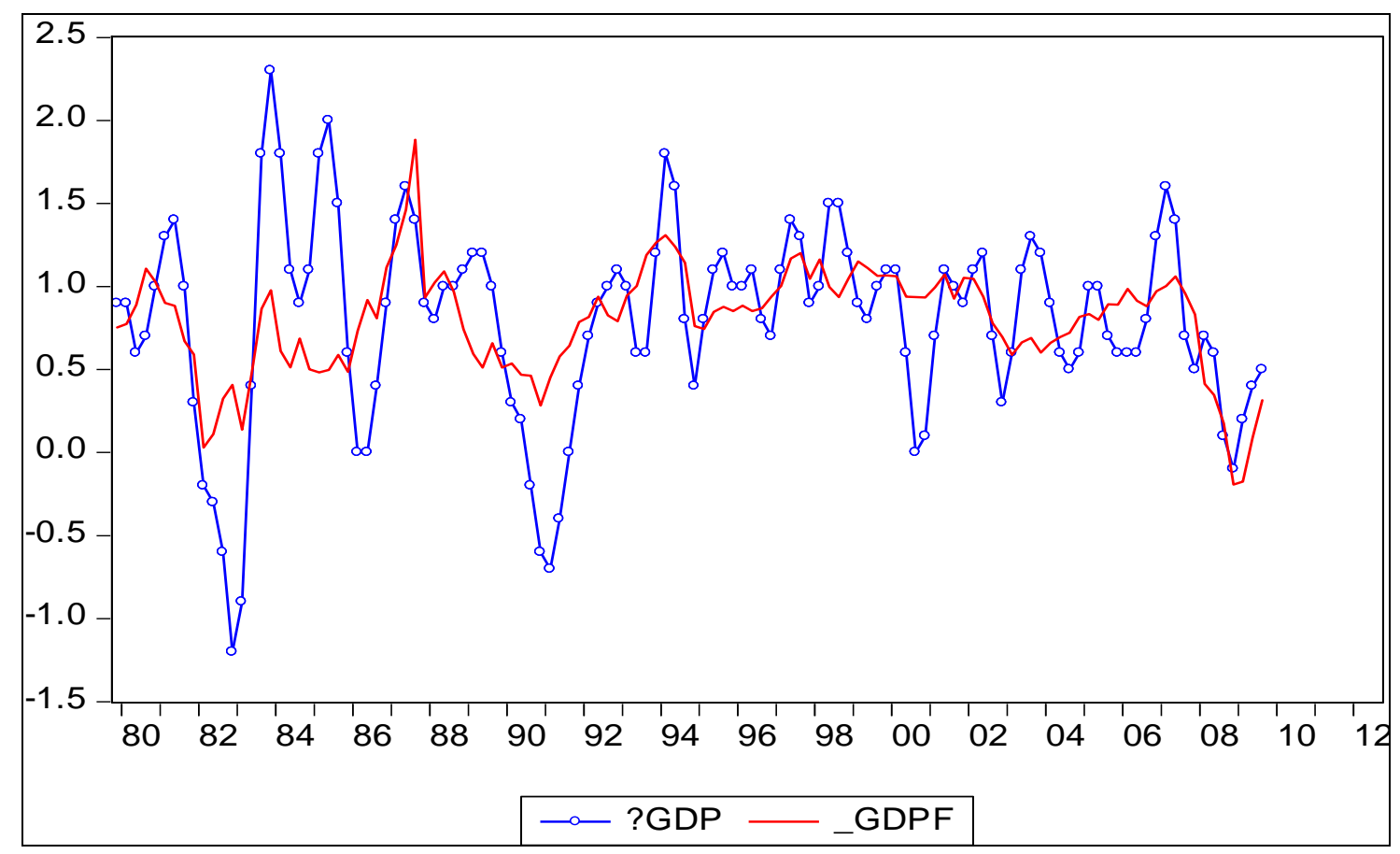

\section{Limitations and Future Research Directions}

Some researchers argue that using financial variables (such as the term structure of interest rates) as predictors of future economic conditions lacks a well-established theoretical foundation (Jochum \& Kirchgässner 1998). The methodologies employed in predicting future economic activities have also been criticised. For instance, although most studies use time series data, they do not consider the nonstationary characteristics of such data. That is, the methodologies used in these studies are too simple and therefore incapable of producing concrete results. As a result of the close interaction between financial variables and real variables, some of the arguments raised against the use of the former may lack popular support. Specifically, the GFC reflects a strong relationship between financial market activities and real economic activities. Another argument is that even though variables, such as term structure, are useful in predicting future economic activities in certain countries, they are not necessarily applicable to other nations. Jochum \& Kirchgässner (1998) replicate the study of Mishkin (1990) for Switzerland and find similar results. However, when the former extended the basic regression by including the known short-term inflation rate and lagged values of the dependent variable, the term structure became non-significant. Nevertheless, this study reflects only one particular case.

Widely noted limitations associated with using financial variables to predict future economics activities are related to forecast methodologies. Numerous researchers confirm that methodological issues and endogeneity problems are common in studies that use social variables. Applying different methodologies or improving existing approaches is therefore a worthwhile endeavour. Further research is needed to improve the methodological aspect of studies that use financial variables to predict future economic activities. More accurate 
indicator models based on financial variables can also be developed using neural networks. The application of neural networks in future economic forecasting is still in its infancy, but a few studies have shown encouraging results (Taylor 1996). Well-known indicator models exhibit poor performance for 1-quarter forecasts because the variables used cannot sufficiently explain the volatility of such predictions (recession or growth rate). Dynamic neural network models are more accurate than linear models by about 5\% (Tkacz \& Hu 1999).

\section{Conclusion}

This study uses a probit model similar to those applied to determining the ability of financial variables to predict future economic activities in other countries. We examine the predictive power of Australian financial variables. The present study extends the work of Estrella (1995), providing similar findings for Australia; such results may differ by country. We incorporate real estate indexes because these are crucial factors for economic growth activities. We also forecast the GDP growth of Australia up to 2012. On the basis of our results, we conclude that most financial variables are suitable for predicting real economic activity. Among these variables are 10-year Treasury bonds and 90-day bank bills under full sample estimation. Furthermore, almost all the variables are useful in predicting future activities under individual estimation. Our results strongly support the use of financial variables to predict future economic activities for policy decisions purposes.

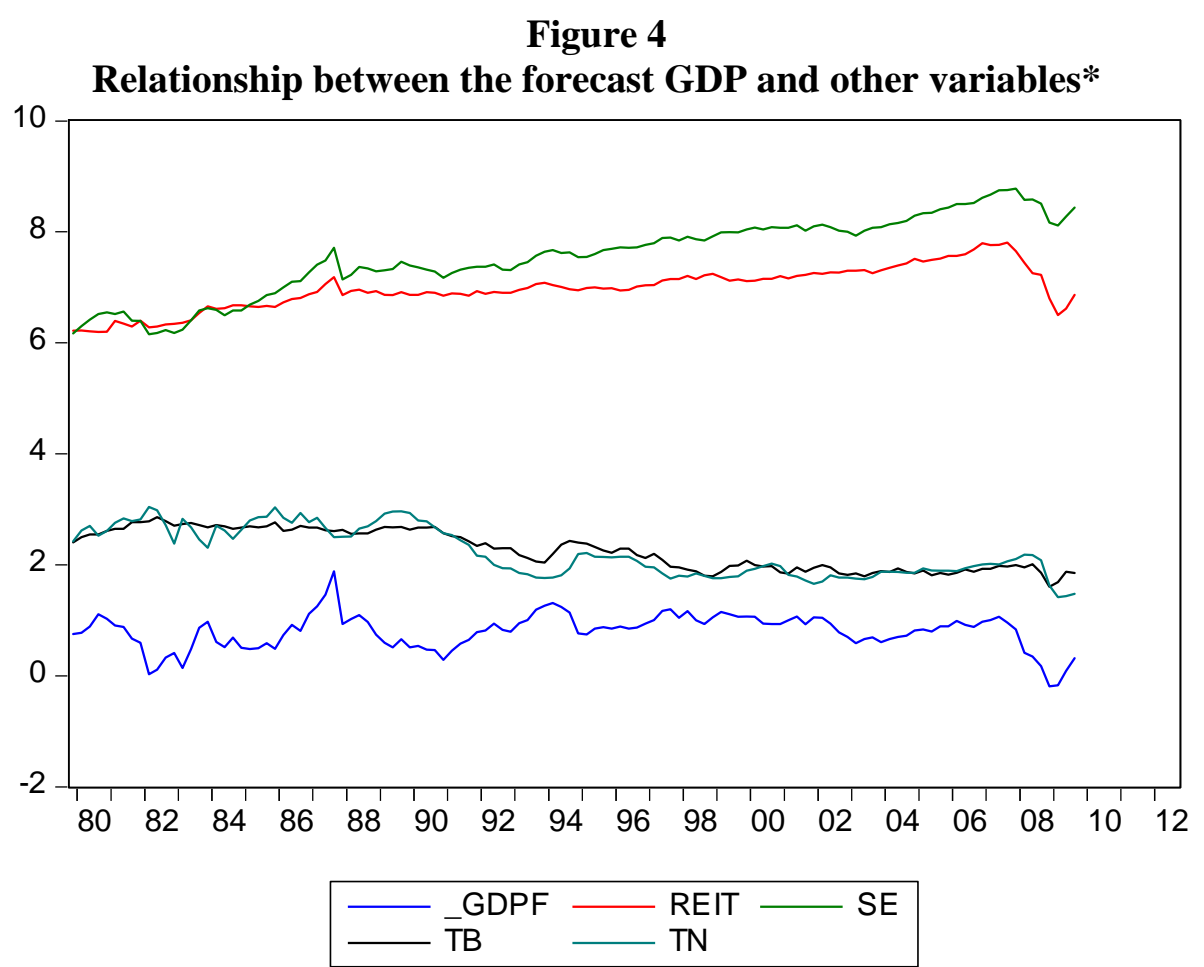

*GDPF $=$ Australian Gross Domestic Product Forecast; REIT = Australian Real Estate Investment Trust Index; SE = Australian Stock Market Index; $\mathrm{TB}=$ Australian Treasury Bond Rate; TN = Australian Treasury Notes Rate 
Edirisuriya | The Predictive Power of Financial Variables

\section{References}

Alles, L 1995, 'The Australian term structure as a predictor of real economic activity', Australian Economic Review, vol. 28, no. 4, pp71-85. http://dx.doi.org/10.1111/j.1467-8462.1995.tb00905.x

Ang, A, Piazzesi, M \& Wei, M 2006, 'What does the yield curve tell us about GDP

Growth?’, Journal of Econometrics, vol. 131, pp359-403. http://dx.doi.org/10.1016/j.jeconom.2005.01.032

Atta-Mensha, J \& Tkacz, G 1998, 'Predicting Canadian recessions using financial variables: A probit approach’, Working Paper 98-5, Bank of Canada.

Beckett, WA 1961, Indicators of Cyclical Recessions and Revivals in Canada in Business Cycle Indicators, G.H. Moore (ed.), (1), 294-322.

Begum, J 1998, "Correlations between Real Interest Rates and Output in a Dynamic International Model: Evidence from G-7 Countries”, IMF Working papers, WP/98/179.

Bernanke, BS 1990, 'On the predictive power of interest rates and interest rate spreads', New England Economic Review, November/December, pp51-68.

Bernard, H \& Gerlach, S 1996, 'Does term structure predict recessions? The international evidence', Working Paper 37, Bank for International Settlements.

Caporale, GM \& Pittis, N 1998, 'Term structure and interest differentials as predictors of future inflation changes and inflation differentials', Applied Financial Economics, vol. 8, pp615-625. http://dx.doi.org/10.1080/096031098332655

Chauvet, M \& Potter, S 2005, 'Forecasting recessions using the yield curve', Journal of Forecasting, vol. 24, no. 2, pp77-103. http://dx.doi.org/10.1002/for.932

Edirisuriya, P 2005 'Predicting power of financial variables: Evidence from Australia', International Review of Business Research Papers, vol. 1, no. 1, pp1-17.

Espinoza, R, Fornari, F \& Lombardi, M 2009, 'The role of financial variables in predicting economic activity’, Working Paper 1108, European Central Bank.

Estrella, A 1995, 'Predicting U.S. recessions: Financial variables as leading indicators', Working Paper 5379, NBER.

Estrella A 2005, 'Why does the yield curve predict output and inflation?', The Economic Journal, vol. 115, pp722-744. http://dx.doi.org/10.1111/j.1468-0297.2005.01017.x

Estrella, A \& Hardouvelis, G 1991, 'The term structure as a predictor of real economic activity', Journal of Finance, vol. 46, pp555-576. http://dx.doi.org/10.1111/j.1540-6261.1991.tb02674.x

Estrella, A \& Mishkin, FS 1998, 'Predicting U.S. recessions: Financial Variables as leading indicators', The Review of Economics and Statistics, vol. 80, pp45-61. http://dx.doi.org/10.1162/003465398557320

Filardo, AJ 1999, ‘How reliable are recession prediction models?’ Economic Review, Second Quarter, pp35-55.

Fisher, C \& Felmingham, B 1998, 'The Australian yield curve as a leading indicator of consumption growth', Applied Financial Economics, vol. 8, pp627-635. http://dx.doi.org/10.1080/096031098332664

Forni, M, Lippi, M, Hallin, M \& Reichlin, L 2003, 'Do financial variables help forecasting inflation and real activity in the euro area?', Journal of Monetary Economics, vol. 50, pp1243-1255. http://dx.doi.org/10.1016/S0304-3932(03)00079-5

Friedman, M \& Kuttner, K 1992, 'Money, income, prices, and interest rates', The American Economic Review, Vol. 82, pp472-492. 
Giacomini, R \& Rossi, B. 2006, 'How stable is the forecasting performance of the yield curve for output growth?', Oxford Bulletin of Economics and Statistics, vol. 68, pp783-795. http://dx.doi.org/10.1111/j.1468-0084.2006.00456.x

Greene, WH 1993, Economic Analysis, $2^{\text {nd }}$ edition, Prentice Hall, Upper Saddle River, New Jersey.

Harvey, C 1988, 'The real term structure and consumption growth', Journal of Financial Economics, vol. 22, pp305-333. http://dx.doi.org/10.1016/0304-405X(88)90073-6

$\mathrm{Hu}, \mathrm{Z}$ 1993, 'The yield curve and real activity', IMF Staff Papers, vol. 40, pp781-806. http://dx.doi.org/10.2307/3867610

Jochum, C \& Kirchgässner, G 1998, 'Is there information about future inflation in the term structure? Empirical results for Switzerland', Discussion Paper 9814.

Junttila, J 2007, 'Forecasting the macroeconomy with contemporaneous financial market information: Europe and the United States', Review of Financial Economics, no. 16, pp149-175. http://dx.doi.org/10.1016/j.rfe.2006.05.001

Karunaratne, ND 2002, 'Predicting Australian growth and recession via the yield curve', Economic Analysis and Policy, vol. 32, no. 2, pp233-250. http://dx.doi.org/10.1016/S0313-5926(02)50031-X

Laurent, R 1988, 'An interest rate based indicator of monetary policy', Federal Reserve Bank of Chicago Economic Perspectives, vol. 12, pp3-14.

Laurent, R 1989, 'Testing the spread', Federal Reserve Bank of Chicago Economic Perspectives, vol. 13, pp22-34.

Lawe, P 1992, 'The term structure of interest rates, real activity, and inflation', Research Discussion Paper 9204, Reserve Bank of Australia.

Mitchell, WC \& Burns, AF 1938, Statistical Indicators of Cyclical Revivals, in Business Cycle Indicators, GH Moore (ed.), (1), 162-183.

Mishkin, FS \& Simon, J 1994, 'An empirical estimation of the Fisher effect in Australia', Research Discussion Paper 9410, Reserve Bank of Australia.

Moneta, F 2005, 'Does the yield spread predict recessions in the euro area?', International Finance, vol. 8, pp263-301. http://dx.doi.org/10.1111/j.1468-2362.2005.00159.x

Moore, GH 1961, Leading and Confirming Indicators of General Business Changes, in Business Cycle Indicators, GH Moore (ed.), (1), 45-109.

Moore, GH \& Shiskin, J 1966, 'Indicators of business expansions and concentrations', Research Occasional Paper 103, NBER.

Panopoulou, E 2006, 'The predictive content of financial variables: Evidence from the euro area’, IIIS Discussion Paper 178, Institute for International Integration Studies, Ireland.

Philip, DE \& Henry, SGB 1994, 'The Use of financial spreads as indicator variables: Evidence for the United Kingdom and Germany’, IMF Staff Papers, vol. 41, pp517525. http://dx.doi.org/10.2307/3867439

Ramanathan, R 1998, Introductory econometrics with applications, $4^{\text {th }}$ Edition, Fort Worth Dryden Press.

Smets, F \& Tsatsaronis, K 1997, 'Why does the yield curve predict economic activities?', Working Paper 49.

Stock, JH \& Watson, MW 1993, A Procedure for Predicting Recessions with Leading Indicators: Econometric Issues and Recent Performance, in J Stock and MK Watson (ed.), Business Cycles, Indicators, and Forecasting.

Stock, JH \& Watson, MW 2001, 'Vector autoregressions', The Journal of Economic Perspectives, vol. 15, no. 4, pp101-115. http://dx.doi.org/10.1257/jep.15.4.101 
Stock, JH \& Watson, MW 2003, 'Forecasting output and inflation: The role of asset prices', Journal of Economic Literature, vol. 41, no. 3, pp788-829. http://dx.doi.org/10.1257/jel.41.3.788

Taylor, JG 1996, Neural Networks and Their Applications, John Wiley \& Sons.

Tkacz, G \& Hu, S 1999, Forecasting GDP growth using artificial neural networks, Bank of Canada, Ottawa.

Valadkhani, A 2003, 'Does the term structure predict Australia's future output growth?', Economic Analysis and Policy, vol. 33, no. 2, pp121-144.

Watson, M 1991, 'Using econometric models to predict recessions', Federal Reserve Bank of Chicago Economic Perspectives, vol. 15, pp14-25.

Wheelock, DC \& Wohar ME 2009, 'Can the Term Spread Predict Output Growth and Recessions? A Survey of the Literature', Federal Reserve Bank of St. Louis Review, vol. 91, pp 419-40. 